\title{
Rural Malay youth leadership and Malaysian herbal entrepreneurship development
}

\begin{abstract}
Malay youth leadership is the key factor for the development of rural Malay herbal entrepreneurship. This herbal entrepreneurship has been running by the elderly family members since start up it. As a result, the involvement of youth leadership for their entrepreneurship development is very limited and decreased their entrepreneurship growth day by day. This study was employed using a phenomenological qualitative research approach with ten rural Malay herbal entrepreneurs in Peninsular of Malaysia through indepth interview of individualôs life experience. It is revealed that youth leadership is the major issue for the development of rural Malay herbal entrepreneurship. The findings suggest that human and financial capital, technical knowledge know-how and government policy are important to increase the involvement of rural Malay youth in herbal entrepreneurship.
\end{abstract}

Keyword: Leadership; Entrepreneurship; Herbal industry; Qualitative phenomenological approach; Government support 